\title{
Evaluation of satellite evapotranspiration estimates using ground- meteorological data available for the Flumen District into the Ebro Valley of N.E. Spain \\ J.G. Ramos ${ }^{1}$, C.R. Cratchley ${ }^{2}$, J. A. Kay ${ }^{2}$, M.A. Casterad ${ }^{3}$, A. Martínez-Cob ${ }^{4}$ and R. Domínguez ${ }^{1}$
}
${ }^{1}$ Instituto de Ingeniería, Universidad Nacional Autónoma de México, UNAM, Av. Universidad 3000, 04510 Coyoacan, Mexico City. Tel:+52(55)56233663, FAX:+52(55)56162798, jramosh@ii.unam.mx
${ }^{2}$ Centre for Arid Zone Studies, University of Wales, Bangor, Wales, United Kingdom.
${ }^{3}$ Centro de Investigación y Tecnología Agroalimentaria de Aragón (CITA), Lab. Asociado de Agronomía y Medio Ambiente (DGA-CSIC), Zaragoza, Spain.
${ }^{4}$ Dept. Genética y Producción Vegetal (EEAD), Lab. Asociado de Agronomía y Medio Ambiente (DGA-CSIC), \\ Zaragoza, Spain.
}

\begin{abstract}
Accurate estimation of actual evapotranspiration $\left(\mathrm{ET}_{\mathrm{a}}\right)$ is essential for effective local or regional water management. At a local scale, ET estimates can be made accurately considering a soil-plant-atmospheric system, if adequate meteorological-ground data or ET measurements are available. However, at a regional scale, $\mathrm{ET}_{\mathrm{a}}$ values cannot be measured directly and the estimates are frequently subject to errors. Although it is possible to extrapolate to the regional scale from local (point) data of meteorological stations, the relative sparse coverage of ground estimate can make this problematic without some spatial analysis to demonstrate the similarity of the climate in the area. The introduction of remote sensing data and techniques offers alternatives both to estimate variables (i.e. radiation) and parameters (i.e. ET) with few spatial restrictions, thus, it provides potential advantages to the regional $\mathrm{ET}_{\mathrm{a}}$ computation. In particular, the use of remote sensing procedures like the Surface Energy Balance based algorithms (SEB) have been successfully applied in different climates, enabling the estimation of $\mathrm{ET}_{\mathrm{a}}$ at local and regional scales. A proper variation of the Surface Energy Balance Algorithm for Land (SEBAL) was applied to four years of data for the Flumen District in the Ebro Basin at the N.E. of Spain. Results obtained show that the remote sensing algorithm can provide accurate daily $\mathrm{ET}_{\mathrm{a}}$ estimations as compared with lysimeter measurements of daily ET values for two crop plots: one with a reference grass and other with maize or wheat as function of the season. Also a comparison between $\mathrm{ET}_{\mathrm{a}}$ and the reference and crop ET values applying the Penman-Monteith method was carried out. The comparison analysis consider an accepted error difference of $1.0 \mathrm{~mm} \cdot \mathrm{d}^{-1}(20 \%$ of error) for local scale, the $\mathrm{ET}_{\mathrm{a}}$ values for the grass show a bias of $0.30 \mathrm{~mm} \cdot \mathrm{d}^{-1}$ against the $\mathrm{ET}_{\text {grass }}$ and a bias of 0.36 $\mathrm{mm} \cdot \mathrm{d}^{-1}$ against $\mathrm{ET}_{\mathrm{o}}$. Differences between $\mathrm{ET}_{\text {maize }}$ or $\mathrm{ET}_{\text {wheat }}$ and $\mathrm{ET}_{\mathrm{a}}$ against their average
\end{abstract}


showed an acceptable agreement for the field with $\mathrm{s}_{\text {diff }} \pm 0.6 \mathrm{~mm} \cdot \mathrm{d}^{-1}$. For the crop fields at regional scale external causes associated to atmospheric and surface variations (i.e. land preparation) rather to the remote sensing algorithm made difficult to determine a percentage of error. Finally, $\mathrm{ET}_{\mathrm{a}}$ values were obtained at regional scale and it was demonstrated that using the remote sensing improve significantly the crop ET estimations computed in the area using traditional methods.

Keywords: Evapotranspiration, SEBAL, MEBES, meteorological data, Ebro Valley, water management.

\section{Introduction}

Today, there are increasing demands on a finite water resource from competing economic sectors. Agriculture is the major user of water especially in arid and semi-arid lands where there is a need to increase food production. However, through the last decade, it has been observed that the increase in agricultural production depends more on the efficient use of water rather than an increase in the total amount of water available (Batchelor, 1999; Perry, 2003). Thus, knowing the efficiency with which water is presently used is key to understand the real water availability and to help establish appropriate strategies and to reduce possible constraints in water resources (Bouwer, 2002; Hillel, 2000; Perry, 1999). In order to achieve this, it is fundamental to have an appropriate knowledge of the spatial diversity (i.e. cropping patterns) and temporal variability (i.e. short-term changes in agro-climatic conditions) of the water, as well as the efficiency of irrigation systems, water storage, and irrigation capacities (Batchelor, 1999; Bouchart and Goulter, 1998; Sarwar et al. 2001). One way to identify the temporal and spatial patterns of water use, how productively water has been used, and where water is being wasted is producing an area wide-mapping of evapotranspiration (ET) (Perry, 2003). As the physics of the ET process is well understood, accurate ET values at local level are available. However, as ET is highly sensitive to various land and atmospheric variables, particularly in their spatially distributed form, it makes regional ET estimations uncertain (Calder, 1998).

The traditional estimation of ET relies on the meteorological and ground data available from nearby weather stations, restricting it's application to small areas. Even at local scale, ET information may not always be available, because very few weather stations measure it or do not satisfy the requirements for computing a reference ET (FAO-24 or FAO-56 later). In 
this context, remote sensing techniques have been shown to be a reliable alternative to estimate ET, since some of the main constraints on suitable and available data can be overcome by providing a precise spatial representation. One important advantage is that it provides detailed and independent ET estimations on a pixel-by-pixel basis.

Although reliable actual ET $\left(\mathrm{ET}_{\mathrm{a}}\right)$ values have been obtained by combining remote sensing techniques with ground-meteorological data (Schultz and Engman, 2001), the application of these techniques is still questioned despite their advantages. Two principal reasons are responsible for the resistance of stakeholders to apply them: a) lack of knowledge about the information provided and its application, and b) concern about some of the empirical assumptions involved in the remote sensing procedures (Doraiswamy et al., 2008). These make the validation of the remote sensing algorithms fundamental since results are not transferable from basin-to-basin without considering the spatial and temporal climatic variability, principally in dry regions (Schmugge et al. 2002). Once the validation has been performed the application of the $\mathrm{ET}_{\mathrm{a}}$ values can be done throughout the whole basin mainly if the weather conditions are stable.

This paper is one outcome of the project to test the reliability and applicability of one proper version of the SEBAL procedure (Surface Energy Balance Algorithm for Land) developed by Bastiaanssen et al. (1998a; 1998b) called MEBES (Surface Energy Balance, in Spanish) in the Flumen District at the NE of Spain, in order to establish it as a suitable tool to compute $\mathrm{ET}_{\mathrm{a}}$ in a current procedure (Ramos, 2005). MEBES is based on the SEBAL version applied in Bastiaanssen and Bandara (2001), and Farah et al. (2004) where $\mathrm{ET}_{\mathrm{a}}$ is estimated by solving the energy balance parameters (soil flux, sensible flux, radiation and latent flux as the residual term). This SEBAL version was chosen since it presented major advantages to compute $\mathrm{ET}_{\mathrm{a}}$ values among other $\mathrm{SEB}$ techniques using both remote sensing and meteorological-ground data for local and regional areas (Ramos, 2005). MEBES is a custommade version for application in regions where weather data availability is constrained due to incomplete data sets even during the satellite acquisition time. Thus, MEBES was applied to four years of data and validated with lysimeter ET measurements at the local level. Also, local $\mathrm{ET}_{\mathrm{a}}$ values were compared using the Penman-Montieth method. Finally, as crop ET estimation values obtained in the Flumen District use conventional methods, such as BlaneyCridle and Hargreaves. Tests were performed to see if $\mathrm{ET}_{\mathrm{a}}$ values could improve these crop ET estimations. This demonstrates if effectively $\mathrm{ET}_{\mathrm{a}}$ values could provide better water management in the Flume District by given a real crop demand of water, considering farm 
practices as land preparation and subsidised crops, that cannot be met by the Blanney-Criddle and Hargreaves methods.

The reason to use the Blaney-Criddle $(\mathrm{BC})$ method in the Flumen District modified by Doorenbos and Pruitt (1977) was based on obtaining a monthly potential ET value by arid regions using a simple equation that does not require several measured meteorological variables, since weather stations available recorded few variables. Thus the method included monthly variables such as mean daytime wind speed, ratio of actual to maximum sunshine hours, temperature, latitude and mean daily percentage of total annual daytime hours registered by basic weather stations and tables (Doorenbos and Pruit, 1977). Also, the Hargreaves (Harg) method was chosen for its simplicity and because it was originally developed as a useful method for irrigation planning and design providing a monthly potential ET value base on the air temperature range (Hargreaves et al., 2003). This temperature range in the Hargreaves method (modified in 1985) implicitly considers the cloudiness thus there was a direct correlation with the relative humidity and vapour pressure deficit and indirect correlation with the wind speed. The 1985-Hargreaves method was accepted as an universally applicable equation (Droogers and Allen, 2002) when historical data is missing or when there is no weather station close to the area of interest. The preferred time step is monthly, but also a five-day period was recommended since daily estimates can be influenced by climate conditions, particularly by wind speed variations and cloud cover (Hargreaves et al., 2003). The FAO-56 Penman-Monteith (PM) method provides a reference evapotranspiration $\left(\mathrm{ET}_{\mathrm{o}}\right)$ from weather station data located in a non-stressed reference crop (grass or alfalfa), with a height of $0.12 \mathrm{~m}$, a surface resistance of $70 \mathrm{~s} \cdot \mathrm{m}^{-1}$ and albedo of 0.23 (Allen et a., 1998). This $\mathrm{ET}_{\mathrm{o}}$ differs from the potential ET values since the latter was defined as the rate of evapotranspiration for an extensive surface of grass (8-15 cm tall) actively growing, completely shaded and not short of water (Doorenbos and Pruitt, 1977). The final ET values in the Flumen District are expressed as crop ET for the main crops sown, thus the crop ET is obtained multiplying the potential or reference ET by a crop factor Kc usually base on the FAO-56 list for different crops.

\section{Description of the study area}

The Flumen District is situated in the Ebro Depression, which corresponds to a zone of flat topography within the Central Ebro Basin (CEB) in NE Spain (Fig. 1) with coordinates between latitudes $41^{\circ} 43^{\prime}$ and $42^{\circ} 03^{\prime}$ 'North, and longitudes $0^{\circ} 32^{\prime}$ and $0^{\circ} 07^{\prime}$ 'West. 
The Flumen District covers an approximate area of 33,730 ha, and it is a subregion of the Riegos del Alto Aragon (RAA, Irrigation lands at the Aragon's Northern Area) system. The area includes the main irrigation system (50 years old) and some enclaves that are settings within the territory but with different geographic characteristics, and old irrigated plains (i.e. huertas, older than six centuries) along the riverbanks. Except for the irrigated areas, the rest of the land is dry with some rainfed agriculture where wheat and barley are the main crops. The Flumen District is bounded by the Flumen and Cinca canals to the north, Flumen River and its acequias (small diversion dams) to the south, and part of the Alcanadre River and its acequias to the east. One important characteristic of almost all rivers in the RAA system is that they have an irregular flow and are subject to salinity problems (CHE, 2002).

For the CEB, Martínez-Cob and Tejero-Juste (2004) reported variations of mean annual precipitation from 354 to $475 \mathrm{~mm}$, air temperature from 13.1 to $14.5{ }^{\circ} \mathrm{C}$, and air relative humidity from 65 to $76 \%$. Wind speeds are categorised as: low (less than $1.0 \mathrm{~m} \cdot \mathrm{s}^{-1}$ ), moderate (from $1.0-2.5 \mathrm{~m} \cdot \mathrm{s}^{-1}$ ) and strong (more than $2.5 \mathrm{~m} \cdot \mathrm{s}^{-1}$ ), although for the Flumen, moderate winds prevail. The topography reinforces the influence of continental winds, which in extreme conditions produces a northwest winter wind called cierzo, and a southeast summer wind called bochorno. The cierzo is the prevailing wind, cold in winter and fresh in summer, but always with a drying action. It imparts a high aridity to the zone throughout the year (CHE, 2002). The bochorno wind is dry and hot and occurs commonly in summer, specifically in July and August, when it has a strong effect on the climate and, in consequence, on the ET. The bochorno can also occur in spring and winter but there is less effect on the ET as the wind is warm and humid. The bochorno is associated with anticyclones or with wind regimes from the South, particularly from the Sahara, so higher levels of dust in the upper atmosphere could be present too.

Typical irrigated lands in the CEB produce vegetable, fodder and cereal crops, and fruit trees. The average plots in the Flumen District are rectangular and less than one hectare. Surface irrigation supplies up to $80 \%$ of the irrigated land, and the remaining $20 \%$ are sprinkler (18\%) and drip (2\%) irrigation systems. (Oficina del Regante, 2003). As water is regarded as a public good, it is provided under a concession system granted for a period of time regulated by the Hydrographical Ebro River Confederation (CHE). In some cases water delivered increases up to $40 \%$ of the farmer's water demanded in order to avoid losses in the network system or by attending their water rights. As there is a necessity to modernise irrigation districts to improve water efficiency, some research has been done in order to compute accurately water demands (Martinez-Cob et al., 1998). Casterad et al. (1992) developed 
a local methodology, IRRIVOL (IRRIgation Volumes), to compute net water volumes in irrigation districts including a combination of meteorological and satellite data. The satellite data was used to generate land cover classification and soil maps. The latter according to the susceptibility of the land for agriculture. The meteorological data was used to compute monthly crop ET using BC or Harg methods. These two methods are preferred since traditionally or basic weather stations only registered precipitation and air temperature. Although, some improvements were done in order to update the meteorological network system introducing automatic weather stations (EMAs), few EMAs were registering the variables to use the Penman-Monteith (PM) method at the moment of the study. One study using the PM equation tested the $\mathrm{ET}_{\mathrm{o}}$ against the lysimeter ET, results indicated a very good correlation (98\%) with a slightly overestimation of $\mathrm{ET}_{\mathrm{o}}$. Other researches were carried out in order to compare $\mathrm{ET}$ values from $\mathrm{BC}\left(\mathrm{ET}_{\mathrm{BC}}\right)$ with the grass lysimeters $\mathrm{ET}$ values given a correction factor of 0.88 (Martinez-Cob et al., 1998). Also, the Hargreaves method was tested in the Flumen area (Martinez-Cob and Tejero-Juste, 2004); ET $T_{\text {Harg }}$ values showed a significant contribution in windy areas, thus the equation was modified according to the windy conditions prevailing in the area. To get the crop ET, potential ET values from BC and Harg are multiplied by a crop coefficient, Kc, that comes from the Kc values list in FAO-56 but adapted to the Aragon conditions, Kcadj (Martinez-Cob et al., 1998). These Kcadj values have been compared against Kc values obtained by lysimeters (reference and seasonal crops under standard conditions) and by a thermal integration considering as the temperature base the one at the moment of sowing. Once crop ET are obtained, the water requirements are computed using the effective precipitation and finally the net water requirements are predicted and mapped. IRRIVOL has been used since 1992 in the Aragon irrigation districts providing a significant tool with slightly differences once comparing the net water requirements with the CHE supplied demands.

\section{Data and methods}

The project evaluated a four-year study period $(1997-2000)$, the available data and the methods followed are described next.

\subsection{Lysimeter ET data}


To compare the $\mathrm{ET}_{\mathrm{a}}$ values, it was necessary to use reliable ET values that can be computed or estimated by different methods. In this case, lysimeters ET measurements were available within the Experimental Farm of the Aula Dei (EEDA-CSIC) in Zaragoza, Spain. Two weighing lysimeters were installed in 1997 in contiguous plots (Fig. 2), one of them was a 1.25 ha covered with grass managed to provide a reference crop according to the FAO-56 guidelines (Allen et al. 1998). The reference crop was Fetusca Arunfinacea cv. Demeter which was regularly irrigated per month (15 times on average in January until May, 21 times in June until August and 6 times in September until December) and cut all year to maintain an average height of $12 \mathrm{~cm}$ (cuttings were from May to October). This crop is very sensitive to hot conditions, thus during summer its growth is slow. Fig. 2 shows the grass plot location and the surrounding plots covered all year by alfalfa. The datalogger recorded lysimeter mass losses every $0.5 \mathrm{~s}$ from which hourly ETo rates were derived. Daily measured ETo values were obtaining summing up the hourly ones. The resolution is $0.05 \mathrm{~mm}$ water depth.

The other lysimeter plot was located next to the grass plot with a size of 1.0 ha and it was covered by maize or wheat; the crop selection depended on the research carried out at that site and varied from year to next. Thus, the four-year study involves crop ET for two maize (variety Juanita) seasons, 1997 and 1998, and two wheat seasons, 1999 and 2000 (Table 1). The continuous research carried out in the zone has permitted accurate crop information about the usual sowing and harvest dates, crop cycle, crop coefficients, irrigation practices and height at the crop stages (Martínez-Cob et al. 1998) to be used. Fig.2 shows the plot bordered by different irrigated crops or fallow plots; the surface cover depends on the research carried out during the year in the zone.

\subsection{Meteorological data}

The meteorological data was collected for the four-year study period (1997 to 2000) from three main sources (Fig. 3):

a) Sariñena and Monflorite Automatic Weather Stations (EMAs) that provide data at 10minute intervals for variables such as precipitation $(\mathrm{P})$, air temperature $\left(\mathrm{T}_{\mathrm{a}}\right)$, relative humidity (RH), wind speed, wind run and atmospheric pressure, and solar radiation (Rs). The Sariñena station was located within the Flumen District, thus changes related to irrigated areas take place (low daytime air temperature, high humidity, low vapour pressure and low wind speed). The Monflorite station is located in a bare soil area located out of the irrigated area. 
b) Twenty Basic Weather Stations (BWS), recording $\mathrm{P}$ and $\mathrm{T}_{\mathrm{a}}$ covered the study area and surroundings, and

c) A portable automatic weather station (CR10-EEAD) was located within the grass referemce lysimeter plot.

Surprisingly, both EMAs had very incomplete records, although the frequency of incomplete data was more significant in Sariñena (77\%) than in Monflorite (42\%). In particular, Sariñena had more data missing (ND) than Monflorite, for 1999 and 2000 years.

In order to assess the reliability of the BSW data, double-mass curves (DMC) were developed for cumulative precipitation $(\mathrm{P})$ and air temperature $(\mathrm{Ta})$ records. This analysis allows identification of how these variables are varying in time and space, thus it helps to determine how ET values can be affected. The result obtained was that the Flumen District and its surrounding area can be divided into North and South at around the $41^{\circ} 52^{\prime}$ latitude (5' North from Sariñena EMA). This shows that the Flumen District is strongly influenced by the pre-Pyrenees climate that corresponds to the Monflorite weather station.

As meteorological data from EMAs was available, $\mathrm{ET}_{\mathrm{o}}$ values were obtained using the PM method, as well as potential ET estimations using Harg and BC equations with BWS data, thus Double Mass Curve (DMC) analysis was developed to test their reliability. Firstly, the test established the relationship between the $\mathrm{ET}_{\mathrm{BC}}$ and $\mathrm{ET}_{\mathrm{Harg}}$ methods. Secondly, it was possible to test the relationship between the ET values computed using PM and BC and Harg equations, because both the EMA and the BWS were located close to each other. Results showed that the ET analysis between PM and Harg was very good for the Sarinena and CR10EEAD stations, although not for Monflorite (Fig.4). The main differences observed in the ET DMC analysis were due to the differences in the ET computation bases since BC and Harg are empirical equations but also the weather and climatic variability, and the surface cover adjacent to the BWS. The weather and climatic variability is fundamental since spatial variations are expected and lead to higher or lower ET values. For the surface cover adjacent, it is important to consider that the reference crop will have grass or alfafa in the area where the weather station is located. However, quite frequently the BWS stations are located in bare soil. During summer (Jul-Aug-Sep) water shortage is prevailing in the area, however the pressure difference on the surface, is the dominant force since the average wind speed is less than $2.0 \mathrm{~m} \cdot \mathrm{s}^{-1}$, this made the rate of evaporation lower compared with vegetated areas.

Also, results demonstrated that the use of only one weather station to represent all the area could cause a significant discrepancy between the single value and the spatial average. For the Flumen District, the ET DMC shows that the area is more influenced by the climate present at 
the Monflorite EMA than at the Sariñena EMA, which has been the station data most used in several researches. Finally, based on the two DMC analyses and knowing the spatial variability of wind speed and haze led to the CEB being finally divided into three specific zones. The Thiessen polygon method was applied according to the area of influence of the Sariñena and Monflorite EMAs and the CR10-EEAD station. The radius of influence was observed as $25 \mathrm{~km}$, since this was the only area where one can choose the reference pixels to run SEBAL (Tasumi, 2003).

\subsection{Remote sensing data}

The satellite images used were from the Landsat platform, Thematic Mapper (TM) and Enhanced Thematic Mapper Plus (ETM+) sensors, covering a study period of four years (1997 to 2000). Fifteen images were acquired to cover a maximum crop-growth stage, they are listed in Table 2. Winter images were not included, because winter crops were in their initial stage (mostly bare soil) or they were not yet sown.

During the image pre-processing techniques two problems were observed: stripe affecting band 6 and the presence of thin clouds or haze. The stripe was solved through the ERDAS destripe function. However, the haze was difficult to remove in two images (Feb-99 and Jul99) even with aerosol-optical models.

Remote sensing land cover classification maps were available for each of the four-years of the study period as result of the application of the IRRIVOL system (Herrero and Casterad, 1998; 1999).

\subsection{Methodology}

The methodology proposed to evaluate the reliability and applicability of MEBES in the Flumen District was as follows:

(a) The process to obtain daily $\mathrm{ET}_{\mathrm{a}}$ values;

(b) Comparison analysis between daily $\mathrm{ET}_{\mathrm{a}}$ with daily lysimeter ET measurements at the EEAD site and daily refrence ET computed by the Penman-Monteith (PM) method; and

(c) A reliability test between monthly $\mathrm{ET}_{\mathrm{a}}$ at a regional scale and crop monthly ET values using the IRRIVOL procedure in the Flumen District for the six main crops growing.

The SEBAL procedure involves both empirical and physical based relationships to obtain $\mathrm{ET}_{\mathrm{a}}$ as the residual term of the Land Surface Energy Balance equation. The algorithm works 
with spectral radiances in the visible, near infrared and thermal infrared regions of the spectrum to determine the input variables for the energy balance. These variables include those controlling the radiative fluxes between surface and the atmosphere above such as radiation $(R)$, surface albedo $\left(\alpha_{0}\right)$ and surface temperature $\left(T_{0}\right)$, and those variables controlling the radiative transfer information of the surface such as vegetation indices (NDVI, SAVI and LAI). Surface emissivity $\left(\varepsilon_{0}\right)$ and surface roughness $\left(\mathrm{z}_{0}\right)$ were computed as functions of the vegetation indices. Once these model variables are calculated, they are used to compute spatial variations of land heat fluxes. Soil heat flux $(G)$ is computed using semiempirical relationships based on vegetation index (i.e. NDVI), and Sensible heat flux (H) is computed using the temperature difference from two specific land surfaces: areas with very high and low evaporation (reference points). At this point, the SEBAL procedure involves an internal calibration of $T_{0}$ that considerably reduces errors in the $T_{0}$ calculation associated with atmospheric corrections and the $\varepsilon_{\mathrm{o}}$ empirically estimated. This is basic to produce a precise $\mathrm{H}$ and Latent heat flux ( $\lambda \mathrm{E})$ computations (Bastiaanssen et al. 1998a; Bastiaanssen et al. Bastiaanssen, 1999).

The $\mathrm{ET}_{\mathrm{a}}$ values obtained are instantaneous (for the date and time of image acquisition), thus to extrapolate into daily ET the evaporative fraction (EF) concept was introduced. The $\mathrm{EF}$ is the ratio of latent heat flux to the available energy, or net-wave radiation $\lambda \mathrm{E} /(\mathrm{Rn}-\mathrm{G})$ considering $\mathrm{G} \approx 0$ for a daily basis. $\mathrm{EF}$ tends to be higher in the morning or evening and it is more variable on cloudy days, EF tends to be most stable at maximum ET, which takes place around midday on clear days (Stewart et al. 1998). This agrees with Lakshmi and Susskind (2001), who noticed that the most suitable satellite data are around at the time of maximum ET (midday), and Boni et al. (2001), who considered that satellite data need to be closed $( \pm 3$ hours) to the hour with the peak of diurnal temperature. In our case, the time for the images used was between 10:30 and 11:00 am. Although, it guarantees that satellite data represents the cumulative heating, and hence, it is sensitive to the partitioning of available energy into sensible and latent turbulent heat flux during the day. If the aerodynamic equilibrium is not maintained between the evaporating surface and the boundary layer above, the stability of the EF during the day, and day to day, is affected. In the study area, one factor that can modify the EF stability, is the bochorno wind, that generates a local advection where is horizontally introduced energy. Thus, the air is compressed, the vertical temperature decreases and the air temperature increases, and together with a stationary hot air without horizontal movement produced a major adiabatic heat. As a result plants close their stomas. The cierzo wind has 
less impact since it is more common in winter where weather conditions are not too extreme as in summer with the bochorno. The cierzo is a prevailing wind in winter but as the bochorno these winds are not present every day, thus these days are easily identified from looking at the $\mathrm{Ta}, \mathrm{RH}$, wind speed and wind direction records in the weather stations.

\section{Results and discussion}

\subsection{Comparison process at local scale}

The comparison at local scale of the $\mathrm{ET}_{\mathrm{a}}$ was carried out at the EEAD site based on the lysimetric plots. Thus, to verify the accuracy of estimated $\mathrm{ET}_{\mathrm{a}}$ values, ET from the lysimeter reference plot (grass maintained under standard conditions according to FAO-56), ET grass, $_{\text {, and }}$ from the crop plot, $\mathrm{ET}_{\text {crop }}$, were used. Additionally, a comparison analysis between $\mathrm{ET}_{\mathrm{a}}$ and $\mathrm{ET}_{\mathrm{o}}$ values, using the Penman-Monteith method with meteorological data from the portable CR10-EEAD weather station located at the reference grass plot, was carried out. This comparison was made on the base that $\mathrm{ET}_{\mathrm{a}}$ represents the actual condition at the plots and they are two energy balance methods. Thus $\mathrm{ET}_{\mathrm{o}}$ at the grass plot, considering a $\mathrm{Kc}$ for grass close to 1, can be compared with $\mathrm{ET}_{\mathrm{a}}\left(\mathrm{ET}_{\mathrm{PM}} \mathrm{Vs} \mathrm{ET}_{\mathrm{a}}\right)$ and in the case of the crop plot, $\mathrm{ET}_{\mathrm{c}}$ was obtaining multiplying $\mathrm{ET}_{\mathrm{o}}$ by the $\mathrm{Kc}$ for maize or wheat obtained from the $\mathrm{Kc}$ values in $\mathrm{FAO}-$ 56 adjusted to the area.

\subsubsection{At the grass reference lysimeter plot}

An important consideration is that the footprint of the lysimeter plots does not overlap precisely with a single thermal pixel from the satellite data. The original thermal pixel size is $120 \mathrm{~m}$ for Landsat5 and $60 \mathrm{~m}$ for Landsat7, whereas the grass plot has an area of 1.25 ha $(100 \times 125 \mathrm{~m})$ and the crop plot $1.0 \mathrm{ha}(100 \times 100 \mathrm{~m})$, thus some thermal contamination from the surroundings is expected. In the case of the grass plot, this variation was reduced because the immediate plots around it were covered with a well-watered crop (alfalfa), thus the $T_{0}$ difference was minimum. However, in the case of the crop field, where vegetation inside and outside of the plot is not always similar in height and amount, the soil surface wetness and $T_{o}$ will introduce an important variation as a result of the thermal contamination. Therefore, two different values for $\mathrm{ET}_{\mathrm{a}}$ were considered: $\mathrm{ET}_{\mathrm{aLys}}$ for the pixel where the lysimeter is located, and $\mathrm{ET}_{\text {aplot }}$ for the mean $\mathrm{ET}$ value obtained from all the pixels falling inside the plot. To 
counteract the pixel contamination in the mean $\mathrm{ET}_{\mathrm{a}}$ values for the plot, a selection of nonaffected $\mathrm{ET}_{\mathrm{a}}$ was achieved looking at the thermal pixel coverage. Those affected by the surroundings were thus non-considered.

The comparison between $\mathrm{ET}_{\text {alys }}$ and $\mathrm{ET}_{\text {grass }}$ and between $\mathrm{ET}_{\text {aplot }}$ and $\mathrm{ET}_{\text {grass }}$ shows a slight variation as expected as the lysimeter is maintained at the same condition as the plot. Also a good agreement was observed with an error of $10 \%$ or less considering an acceptable error for field $\mathrm{ET}_{\mathrm{a}}$ measurements of $1 \mathrm{~mm} \cdot \mathrm{d}^{-1}$ (Bastiaanssen, 2000). $\mathrm{ET}_{\mathrm{a}}$ values from the surrounding (alfalfa) plots were not considered since ET from alfalfa is 1.2 to 1.3 times higher than ET from grass. Errors higher than $10 \%$ were observed under conditions of bochorno with $\mathrm{ET}_{\mathrm{a}}$ values half $\mathrm{ET}_{\text {grass }}$ ( $45 \%$ of error) and with presence of haze observed in the image with $\mathrm{ET}_{\mathrm{a}}$ values $15-20 \%$ lower than $\mathrm{ET}_{\text {grass. }}$

As the size of the plot is small compared with the thermal pixel, the $\mathrm{ET}_{\text {aplot }}$ can be used as the value to be used for the local analysis, $\mathrm{ET}_{\mathrm{a}}$. In this way, the bias obtained between $\mathrm{ET}_{\text {grass }}$ vs $\mathrm{ET}_{\mathrm{a}}$ was $0.29 \mathrm{~mm} \cdot \mathrm{d}^{-1}$ with a standard deviation of the difference (that is the measure of the

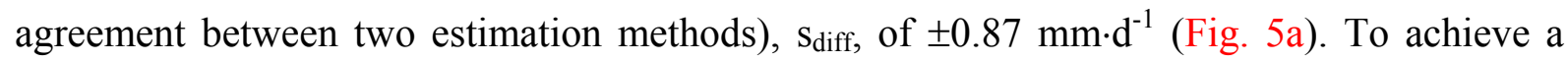
good agreement $s_{\text {diff }}$ needs to be close to zero where the ET from the two methods provides similar values. In this case the scatter in the ET values for both methods was high reducing the agreement. Looking at the outlier points crossing the upper and lower limits, they correspond to the images from Aug-99, Apr-99 and Aug-98, where external factors to the remote sensing procedure are the bochorno in August (high Ta, high RH and calm for wind) and haze in April (from the image) (Fig. 6). Removing them for the analysis provides a better relationship between the estimated $\mathrm{ET}_{\text {grass }}$ and $\mathrm{ET}_{\mathrm{a}}$ with a bias $0.07 \mathrm{~mm} \cdot \mathrm{d}^{-1}$ and $\mathrm{s}_{\text {diff }}$ of \pm 0.35 $\mathrm{mm} \cdot \mathrm{d}^{-1}$ being the outlier point Mar-00.

The bochorno effect as was mentioned above introduces a local advection that coupled with the lysimeters size and the surrounding dry advective areas cannot be observed by the $\mathrm{ET}_{\mathrm{a}}$ values since it works for regional advection. In the case of haze, it was present in the image although rain was observed the day before the image acquisition. Haze is variable in wavelength, space and time, and attenuate the signal reaching the sensors. Theoretically, the rain washes the haze, but if the rain is light, then the haze can be present again. Also, an increment in humidity has been related to haze, as well as wind speed which in arid areas could resuspend particles and temperature is depleted around 5 to $10{ }^{\circ} \mathrm{C}$.

The comparison between $\mathrm{ET}_{\mathrm{PM}}$ vs $\mathrm{ET}_{\mathrm{a}}$ gave a bias of $0.36 \mathrm{~mm} \cdot \mathrm{d}^{-1}$ with an agreement of $\pm 0.85 \mathrm{~mm} \cdot \mathrm{d}^{-1}$ (Fig. 5 b); the outliers were Aug-99 and Apr-99 with Mar-00 crossing the upper 
limit. Also, removing Aug-99, Apr-99 and Aug-98 images, the bias was reduced to 0.22 $\mathrm{mm} \cdot \mathrm{d}^{-1}$ with a $\mathrm{s}_{\text {diff }}$ of $\pm 0.48 \mathrm{~mm} \cdot \mathrm{d}^{-1}$, improving the agreement between $\mathrm{ET}_{\mathrm{a}} \mathrm{Vs}_{\mathrm{BM}} \mathrm{ET}_{\mathrm{PM}}$ being the outlier points Mar-00 Aug-00 and Aug-97.

In general, the agreement observed between $\mathrm{ET}_{\text {grass }} \mathrm{vs} \mathrm{ET}_{\mathrm{a}}$ and $\mathrm{ET}_{\mathrm{a}} \mathrm{Vs}_{\mathrm{ET}} \mathrm{T}_{\mathrm{PM}}$ in Fig. 6 was less than $1 \mathrm{~mm} \cdot \mathrm{d}^{-1}$ and presented a constant scatter.

\subsubsection{At the crop lysimeter}

From the thirteen image dates, three crop lysimeter ET values were missing, two in 1997 (Apr $2^{\text {nd }}$ and Aug $24^{\text {th }}$ ) and one in $2000\left(\operatorname{Aug} 8^{\text {th }}\right)$. The reasons are that in 1997, the lysimeter was installed, whereas in 2000 the cover was bare soil and the lysimetric measurements were stopped after harvesting. Fig. 7 shows the distribution of the differences between ET $_{\text {maize or }}$ wheat and $\mathrm{ET}_{\mathrm{a}}$ against their average. The general agreement between the two methods was fair with $\mathrm{s}_{\text {diff }}$ of $\pm 1.50 \mathrm{~mm} \cdot \mathrm{d}^{-1}$, if one considers an acceptable $\mathrm{ET}_{\mathrm{a}}$ error of $0.5 \mathrm{~mm} \cdot \mathrm{d}^{-1}(10 \%)$ (Bastiaanssen, 2000). In order to explain the $s_{\text {diff }}$ figure, in the case of maize sowing in 1997 and 1998, it was observed for 1997 that only for Jul-97 (DOY 188) was it possible to make a comparison since for Apr-97 (DOY92) the lysimeter was not yet installed and for Aug-97 (DOY127) it had failed but was fixed for the next crop season (Fig. 8). In the case of the CR10-EEAD weather station there was no data recorded the same day as the lysimeter, thus $\mathrm{ET}_{\mathrm{c}}$ was available also only for July. In 1998, the differences observed in DOY127, eight days before sowing, could correspond to the impact of irrigation as a common land preparation practice is to wash salts, this increases the effect of the thermal pixel contamination. In Aug98 (DOY233) the image was associated to the bochorno wind effect and its local advection.

ET deviations in 1999 for wheat showed $\mathrm{ET}_{\mathrm{a}}$ values higher than $\mathrm{ET}_{\text {wheat }}$ and $\mathrm{ET}_{\mathrm{c}}$ for the crop cycle. On the contrary, wheat in 2000 presented $\mathrm{ET}_{\mathrm{a}}$ values with a good correspondence with $\mathrm{ET}_{\text {wheat }}$ and $\mathrm{ET}_{\mathrm{c}}$ values. As 1999 was a drought year this will affect the plant growth and more water was required to avoid plant wilting thus a higher ET was expected. Additionally, the high $\mathrm{ET}_{\mathrm{a}}$ values observed in April 24 1999 (DOY114), where the rate of evapotranspiration is not high, were related to wet conditions (rain or irrigation). The effect for rain or irrigation was not very significant in the grass reference plot where wet conditions did not differ considerably from normal days since grass is a very well watered crop. However, on the crop plot the impact of wet soil within the canopy, the intercepted water and the thermal contamination from the grass reference plot nearby is very important. 
A thermal band inspection of the lysimeter areas verified the presence of several thermal pixels falling within the lysimetric plots but also in the area adjacent. This situation was observed in the image of June $11^{\text {th }} 1999$. This blurred effect could be considerably reduced using Landsat7 images where the thermal pixel size is $60 \times 60 \mathrm{~m}$, thus increasing the possibility that at least an entire non-contaminated pixel falls inside the plot. This can be associated to images for 2000 which presented the best agreement (Fig.8a).

Finally, on August $14^{\text {th }} 1999$, the bochorno wind was present, however under bare soil the local advection could be less significant, for this reason $\mathrm{ET}_{\mathrm{a}}, \mathrm{ET}_{\text {wheat }}$ and $\mathrm{ET}_{\mathrm{c}}$ present a good agreement.

Removing those days that correspond to irrigation and bochorno and plotting the differences between $\mathrm{ET}_{\text {maize }}$ or $\mathrm{ET}_{\text {wheat }}$ and $\mathrm{ET}_{\mathrm{a}}$ against their average showed an acceptable agreement for the field (Fig. $8 \mathrm{~b}$ ) with $\mathrm{s}_{\text {diff }} \pm 0.6 \mathrm{~mm} \cdot \mathrm{d}^{-1}$. However, the sampling number was reduced to five dates, too small to estimate the standard deviation of the differences, but it is evident that the scatter is substantially reduced improving the agreement between the methods tested.

\subsubsection{Monthly SEBAL ET values at local scale}

Remote sensing ET estimates rely on availability of the satellite images. However, there are limitations on image availability and on image suitability, in particular for Landsat images, since satellite overpass is every 16 days and images may be unsuitable because of clouds, haze, dust or ground conditions. As it is not possible to take one image per day covering the crop cycle it is desirable to extrapolate daily $\mathrm{ET}_{\mathrm{a}}$ values to longer periods. In this case, a monthly $\mathrm{ET}_{\mathrm{a}}$ extrapolation was required for the period represented by each image, thus the procedure suggested by Morse et al. (2000) considering the reference ET as an index of the relative change in weather was used. This procedure only is applicable if ET for the entire image area changes in proportion to the change in the reference ET at the index weather site, otherwise the area needs to be divided as climate regions. Thus, the cumulative reference ET is computed for the month related to the image using the Penman-Monteith method; the reference crop was clipped grass. Then, the index, $\mathrm{Km}$, is computed dividing the cumulative $\mathrm{ET}_{\mathrm{o}}$ for the month of the image by the $\mathrm{ET}_{\mathrm{o}}$ for the image day. Finally, $\mathrm{Km}$ is multiplied by daily $\mathrm{ET}_{\mathrm{a}}$ for each pixel of the image. 


$$
\begin{gathered}
K m=\frac{\sum_{j=1}^{n} \text { daily } E T_{o}}{\text { day image } E T_{o}} ; j=\text { day of the month } \\
\text { cumulative } E T_{a}=\sum_{i=1}^{n}\left(E T_{a}\right)_{i} *(K m)_{i} ; \quad i=\text { pixel of the image }
\end{gathered}
$$

Fig. 9 shows monthly $\mathrm{ET}_{\mathrm{a}}\left(\mathrm{ET}_{\mathrm{acum}}\right)$ values for the four-year study period plotted together with monthly $\mathrm{ET}_{\text {grass }}$ and $\mathrm{ET}_{\mathrm{o}}$ values excluding Aug-98, Apr-99 and Aug-99, which were those months with problems (haze and bochorno). For almost every year, $\mathrm{ET}_{\mathrm{acum}}$ values correspond very well with the monthly $\mathrm{ET}_{\text {grass }}$ measurements or monthly $\mathrm{ET}_{\mathrm{o}}$ computed by Penman-Monteith (Table 3). However, in 2000 ET $_{\text {ocum }}$ were higher than cumulative ET values observed for the lysimeter and MEBES. As the lysimeter and the CR10-EEAD station are located at the same plot, the same variation was expected. Thus the different can be related to the $\mathrm{Kc}$, although this value was adjusted to the area it was based on the FAO-56 Kc list.

For the monthly maize or wheat lysimeter ET comparison, daily crop ET values were limited to those dates without events (rain, irrigation and cut) and for the crop cycle. These days were also removed from $\mathrm{ET}_{\text {acum }}$ values and crop cumulative $\mathrm{ET}$, in order to have the same variation. $\mathrm{Km}$ computation was used to obtain monthly $\mathrm{ET}_{\mathrm{a}}$ values. For the cumulative crop ET as result of the multiplication between $\mathrm{ET}_{\mathrm{o}}$ and $\mathrm{Kc}$, the $\mathrm{Kc}$ value applied was the adjusted value to the area based on the FAO-56 list. Results were plotted in Fig. 10.

As is observed in Fig. 9, significant differences were obtained for Jul-97 and Aug-97 where cumulative $\mathrm{ET}_{\mathrm{a}}$ values under-estimated cumulative $\mathrm{ET}_{\text {maize }}$ and $\mathrm{ET}_{\mathrm{c}}$ values. In 1998, only $\mathrm{ET}_{\mathrm{a}}$ for July was close to the $\mathrm{ET}_{\text {maizecum }}$ and $\mathrm{ET}_{\text {ccum }}$ values, although the differences in May-98 could be associated with land preparation or the influence of the thermal contamination as explained before related to the lysimeter size. For wheat the situation was interesting, the 1999 results show significant differences between the lysimeter cumulative ET and both MEBES and the crop ET values (Fig. 9c). As $\mathrm{Kc}$ is a theoretical value highly dependent on the actual crop conditions, it is not surprising that as 1999 was the driest year this modified the crop development, thus Kc used to obtain the crop ET from the $\mathrm{ET}_{\mathrm{o}}$ did not consider this effect. In 2000, the monthly wheat ET shows a good agreement between $\mathrm{ET}_{\text {wheatcum }} \mathrm{Vs}_{\mathrm{E}} \mathrm{ET}_{\text {acum }}$ values but a slow growing from January to May was present in the crop development. This crop development was not observed for $\mathrm{ET}_{\text {ccum }}$ but again $\mathrm{Kc}$ was a theoretical value compared with the other two methods where the Kc represents the actual 
condition. This situation shows that the remote sensing algorithm is sensitive to the crop conditions and variations are more related to the thermal contamination and the lysimeters size.

\subsection{Reliability at regional scale Flumen district}

In order to test the reliability to use MEBES instead IRRIVOL at the Flumen District, the test was achieved on a monthly basis for the six main crops growing in the area (alfalfa and forage, barley, maize, rice, sunflower and wheat). Although BC and Harg, have a different basis than the Penman-Monteith and the MEBES methods, the traditional use of the first equations in the area made this comparison important since improvements can be achieved using the remote sensing method as was demonstrated at local scale.

Table 4 shows the ET results percentage of error obtained between $\mathrm{ET}_{\mathrm{BC}}$ and $\mathrm{ET}_{\mathrm{a}}$ for the six main crops. $\mathrm{ET}_{\mathrm{BC}}$ was achieved multiplying potential $\mathrm{ET}_{\mathrm{BC}}$ by the Kc obtained from the FAO-56 list and adjusted to the local conditions. An acceptable error of $20 \%\left(1 \mathrm{~mm} \cdot \mathrm{d}^{-1}\right)$ was considered and Aug-97, Aug-98, Aug-99 and Mar-00 were excluded from the analysis due to the bochorno and haze errors associated to these months. The $\mathrm{ET}_{\mathrm{a}}$ values for the remaining nine months studied were included even if they were out of the growing season for that type of crop. The reason is to cover possible land preparation, crop rotation or a second crop growth.

Significant differences were observed in Table 4 between $\mathrm{ET}_{\mathrm{BC}}$ and $\mathrm{ET}_{\mathrm{a}}$, in particular for rice (Jul-97 and May-98) and sunflower (Jun-99 and Jun-00) with only two values with differences less than $1 \mathrm{~mm} \cdot \mathrm{d}^{-1}$. The reason for the differences with rice in May-98 probably is due to the time for sowing. However, in the case of Jul-97, the reason can be found in the irrigation practice that is by constant flooding. According to Dr. Casterad (personal communication) and Xiao et al. (2002), the standing water background in rice paddies affects the spectral reflectance of rice, the sensitivity of spectral vegetation indices and the $T_{0}$ that are lower than would be observed for this crop under a different irrigation system. Thus, rice paddies could be regarded by the satellite as shallow water bodies. Looking at the mean $\mathrm{ET}_{\mathrm{a}}$ values for open water bodies present in the image, the range was from 5.3 to $8 \mathrm{~mm} \cdot \mathrm{d}^{-1}$ in July. These water $\mathrm{ET}_{\mathrm{a}}$ figures were more similar to the $\mathrm{ET}_{\mathrm{BC}}$ values for rice until May, then the canopy have a major influence. Also, it is important to consider that as the paddy is under nostressed conditions and soil saturated the Kc value for rice was major than 1.1. 
ET results for sunflower displayed a poor agreement between the methods used. The situation for sunflower cultivation in the area is very unusual, due to the subsidy policy of the CAP (Common Agricultural Policy - European Union), large areas were cultivated, although the yield was low. Farmers provided very little maintenance to the crop after receiving the subsidy. Additionally, this crop is frequently planted on slopes, where it receives water due to seepage. The seepage, because the structural changes of the soil, has a high concentration of salts (Santos, 2003). This helps to explain the variations observed between $\mathrm{ET}_{\mathrm{a}}$ and $\mathrm{ET}_{\mathrm{BC}}$.

Maize variations were from $5 \%$ to $30 \%$, except in May-98 when the error was $48.6 \%$ although the actual difference was $0.99 \mathrm{~mm} \cdot \mathrm{d}^{-1}$. The possible causes of these variations could be related to the use of a theoretical Kc that did not consider climatic variations and the plant management based on the fact that maize is sowing in May.

Barley and wheat showed a better correlation between $\mathrm{ET}_{\mathrm{BC}} \mathrm{vs} \mathrm{ET}_{\mathrm{a}}$. Although from Table 2 , one can observe some important variations or data missing in the year 2000 , this is because the two crops were classified together as winter cereals in the year's data and these variations are related to the different crop stages. Removing the $\mathrm{ET}_{\mathrm{a}}$ values in 2000 , the correlation between the two methods improves considerably; however, the size of the sample was reduced to only four months data. Finally, alfalfa and forage (AFFOR) were the crops that provided a better agreement. May-98 was the single month with a difference higher than 1.0 $\mathrm{mm} \cdot \mathrm{d}^{-1}$. March and April 1999, presented differences less than $1 \mathrm{~mm} \cdot \mathrm{d}^{-1}$, although, the percentage error for these months was about $20 \%$.

The results above indicated a high sensitivity of the remote sensing technique to the type of surface cover that was not reflected by traditional ET computations (Harg, BC and PM inclusive) probably because the Kc impact. Thus, one can conclude that the relationships observed were because $\mathrm{ET}_{\mathrm{a}}$ was reflecting the real crop conditions, this means the influence of surface cover and the surrounding areas effect, not because of a bad performance of the remote sensing algorithm procedure.

\section{$4 \quad$ Summary and conclusions}

The validation at the EEAD site showed a very good agreement for $\mathrm{ET}_{\mathrm{a}}$. It was clear that the climatic and meteorological conditions observed at the EEAD as well as the crop conditions were significant in the estimation of the $\mathrm{ET}_{\mathrm{a}}$ values. The project recognised that certain atmospheric conditions significantly impact $\mathrm{ET}_{\mathrm{a}}$ estimates. Diffuse haze (often 
associated with rain on subsequence days) and the bochorno wind (associated with an increment of the sensible heat), both introduce uncertainties.

The validation at the BWS and EMAs gives confidence in the remote sensing technique at these locations and justifies the validation of MEBES applied to irrigation lands, specifically to the Flumen District.

The validation of the ETa values in the Flumen District confirms that the remote sensing techniques are sensitive to the crop conditions and are affected by the climatic and meteorological conditions. The variations observed for the six main crops growing in the Flumen were:

a) For full cover and well-watered crops such as alfalfa and fodder, and winter cereals, mean monthly $\mathrm{ET}_{\mathrm{a}}$ values compare well with mean monthly $\mathrm{ET}_{\mathrm{BC}}$ values. As the remote sensing algorithm is a thermal and radiation balance, and $\mathrm{dT}$ is almost zero, $\lambda \mathrm{ET}$ is defined by Rn-G. The soil flux for well-watered vegetation is 0.1 times $\mathrm{Rn}$, thus basically ET depends on the radiation parameter.

b) For non-full cover crops such as maize and sunflower, the differences were significant, although they can be related to the plan management, the $\mathrm{ET}_{\mathrm{a}}$ seems to be more accurate since crop ET is restricted to the Kc values that only cover the crop growth cycle.

c) For rice, MEBES provides a poor correlation. For rice paddies the albedo starts at less than 1.0 values increasing during the growing season, which is affected by the change from water body to canopy. As result, $\mathrm{EF}$ is major than 1.0, thus $\mathrm{ET}_{\mathrm{a}}$ needs to be higher, however the $\mathrm{Kc}$ value used to compute crop $\mathrm{ET}_{\mathrm{BC}}$ was always major than 1.1 including those months without canopy since soil is saturated as consequence of the flooding irrigation, in consequence this will increase ET.

As the Hargreaves or Blaney-Criddle was used for the comparison, some uncertainties were present related to their original bases and they need to be considered to avoid wrong interpretation of the results. In general, the $\mathrm{ET}_{\mathrm{a}}$ results show fair agreement for non-full cover crops, while for full cover crops the agreement with $\mathrm{ET}_{\mathrm{BC}}$ was good. However, the variations observed correspond better to the actual conditions at the ground. Thus, the $\mathrm{ET}_{\mathrm{a}}$ values could be the right ones and the final agreement is good. However, more work is recommended using a larger number of images in order to analyse the different stages of the crop cycles and to reduce the interpolation period between image acquisition dates. Also, the reference "cold" pixel selection needs to be reviewed for a more characteristic dry pixel in order to understand the bochorno and cierzo impact. The former because of the advection effect where ET 
exceeds Rn-G under wet conditions, and the latter because of the dT variation in dry regions. This will provide a comparison analysis that makes it easier to observe the advantages using the SEB methods rather than the traditional ones in large areas to cope more accurately with the growing season and water requirements for each crop.

\section{Acknowledgements}

The authors wish to express their gratitude to Dr. Richard Allen, Dr. W. Bastiaanssen, Dr. Gieske and Dr. Juan Herrero for their advice and help to understand the remote sensing technique and the variations at the ground. Dr. Casterad at the Research and Technologic Centre for Agro-food (CITA) in Zaragoza, Spain for her advice and access to the IRRIVOL information. The authors gratefully acknowledge the financial support of DGAPA-UNAM and CONACyT, Mexico. Also, the authors wish to thank the support received during the fieldwork in the CITA, Zaragoza, Spain.

\section{List of Symbols}

$\begin{array}{ll}\alpha_{o} & \text { Surface albedo } \\ \varepsilon_{o} & \text { Surface emissivity } \\ \mathrm{EF} & \text { Evaporative fraction [-] } \\ \mathrm{ET}_{\mathrm{a}} & \text { Actual or real evapotranspiration } \\ \mathrm{ET}_{\text {grass }}, & \text { ET form the lysimeter grass and crop plots } \\ \mathrm{ET}_{\text {wheat or maize }} & \\ \mathrm{ET}_{\mathrm{c}} & \mathrm{ET}_{\mathrm{o}} \times \mathrm{Kc} \\ \mathrm{ET}_{\mathrm{o}} & \text { Potential or reference crop evapotranspiration } \\ \mathrm{G} & \text { Flux density of soil heat at the surface, W. } \mathrm{m}^{-2} \\ \mathrm{H} & \text { Flux density of sensible heat into the air, W. } \mathrm{m}^{-2} \\ \mathrm{Kc} & \text { Crop coefficient } \\ \mathrm{Km} & \text { Coefficient } \\ \mathrm{LAI} & \text { Leaf Area Index } \\ \mathrm{NDVI} & \text { Normalised Difference Vegetation Index } \\ \mathrm{P} & \text { Precipitation } \\ \mathrm{R} & \text { Solar radiation, W. } \mathrm{m}^{-2} \\ \mathrm{SAVI} & \text { Soil Adjusted Vegetation Index } \\ \mathrm{S}_{\mathrm{diff}} & \text { Standard deviation of the difference } \\ \mathrm{T}_{\mathrm{a}} & \text { Air temperatura, }{ }^{\circ} \mathrm{C} \\ \mathrm{T}_{\mathrm{o}} & \text { Surface temperature } \\ \mathrm{z}_{\mathrm{o}} & \text { Surface roughness } \\ \lambda \mathrm{E} & \text { Flux density of latent heat into the air, W. } \mathrm{m}^{-2}\end{array}$

\section{References}


[1] Batchelor C. (1999). Improving water use efficiency as part of integrated catchment management. Agricultural Water Management, 40, 249-263.

[2] Perry C. (2003). Irrigation Reliability And The Productivity Of Water: A Proposed Methodology Using Evapotranspiration Mapping. ICID Workshop on Remote Sensing of ET for Large Regions, 17 Sept. 2003.

[3] Bouwer H. (2002). Integrated water management for the $21^{\text {st }}$ Century: problems and solutions. $J$. of irrigation and drainage Engineering, 128, 4, 193-202.

[4] Hillel D. (2000). Salinity management for sustainable irrigation. Integration science, enviroment, and economic, pp.92, The World Bank, Rural Development Department. ISBN: 0-8213-4773-X. Washington, USA.

[5] Perry C. J. (1999). The IWMI waterresources paradigm-definitions and implications. Agricultural Water Management, 40, 45-50.

[6] Bouchart F.J.C. and Goulter I.C. (1998). Is rational decision making appropriate for management of irrigation reservoirs? Water Resources Planning and Management, 124, 6, 301-309.

[7] Sarwar A, Bastiaanssen W.G.M. and Feddes R.A. (2001). Irrigation water distribution and longterm effects on crop and environment. Agricultural Water Management, 50, 125-140.

[8] Calder, I. R. (1998). Water-resource and land-use issues. SWIM Paper 3. International Water Management Institute. ISBN: 92-9090-361-9. Colombo, Sri Lanka.

[9] Schultz G. A. and Engman E.T. (2001). Present Use and Future Perspectives of Remote Sensing in Hydrology and Water Management. Remote Sensing and Hydrology 2000. IAHS Publ. No. 26, 545-551. Oxford, Great Britain.

[10] Doraiswamy P., Akhmedov B., Milak S. and Stern A. (2008). Remote sensing and modelling methods for crop grain yield assessment. IGARSS 2008 Geosciences and Remote Sensing: the next generation Proceedings, IEEE, July 6-11, 2008, Boston, Massachusetts, USA.

[11] Schmugge T. J., Kustas W. P., Ritchie J. C., Jackson T. J., and Rango A. (2002). Remote sensing in hydrology. Advances in Water Resources, 25, 1367-1385.

[12] Bastiaanssen W.G.M., Menenti M., Feddes R.A. and Holtslag A.A.M (1998a). A remote sensing surface energy balance algorithm for land (SEBAL), Part 1: Formulation. J. of Hydrology, 212213, 198-212.

[13] Bastiaanssen W.G.M., Pelgrum H., Wang J., Ma Y., Moreno J., Roerink G.J. and van der Wal T. (1998b). The Surface Energy Balance Algorithm for Land (SEBAL): Part 2 validation, J. of Hydrology. 212/213: 213-229.

[14] Ramos J. G. (2005). Assessment of Water Use Efficiency in the Flumen Irrigation District, Aragon, Spain, through Remote Sensing and Meteorological Data: Repercussions and Possibilities of New Actions to Improve Water Management Strategies. PhD Dissertation, School of Agriculture and Forest Sciences, University of Wales, Bangor, 08/03/2005. Great Britain.

[15] Bastiaanssen, W.G.M. and Bandara K.M.P.S. (2001). Evaporative depletion assessments for irrigated watersheds in Sri Lanka, Irrigation Science, vol 21(1), 1-15

[16] Farah H. O., Bastiaanssen W. G. M. and Feddes R. A. (2004). Evaluation of the temporal variability of the evaporative fraction in a tropical watershed. Int. Journal of Applied Earth Observation and Geoinformation, 5-5, 129-140.

[17] Doorenbos J. and Pruitt W.G. (1977). "Crop Water Requirements", Irrigation and Drainage Paper No.24, FAO, Rome, 144.

[18] Hargreaves G.H., F.ASCE and Allen R.G. (2003). History and evaluation of Hargreaves evapotranspiration equation. J. of Irrigation and Drainage Engineering, Jan-Feb, 53-63.

[19] Droogers P. and Allen R.G. (2002)Estimating reference evapotranspiration under inaccurate data conditions. Irrigation Drainage System, 6, 1, $33-45$.

[20] Allen R.G., Pereira L.S., Raes D. and Smith M. (1998). Crop Evapotranspiration. Guidelines for Computing Crop Water Requirements. Irrigation and Drainage, Paper No. 56, pp.300. UN Food and Agriculture Organisation. Rome, Italy.

[21] CHE (2002). Confederación Hidrográfica del Ebro. [Web page consulted in March, 2002]: $<$ www.oph.chebro.es $>$. (in Spanish) 
[22] Oficina del Regante (2003). Los regadíos en Aragón. Oficina del Regante, Gobierno de Aragón. [Web page consulted in February 2004]: (in Spanish)

$<$ http://web.eead.csic.es/oficinaregante/mapas/mapas28.htm $>$

[23] Martínez-Cob A., Faci J.M., and Bercero A. (1998). Evapotranspiración y Necesidades de Riego de los Pirncipales Cultivos en las Comarcas de Aragón. Institución Fernando El Católico, 223 pp., Zaragoza, Spain.

[24] Casterad M.A., Arán M., Herrero J. and Albizua L. (1992). Estimación de superficies de cultivos en pequeños regadíos mediante encuesta de terreno y datos de satellite. Agronomie, 12, 661668.

[25] Martínez-Cob A. and Tejero-Juste M. (2004). A wind-based qualitative calibration of the Hargreaves ET0 estimation equation in semiarid regions. Agricultural Water Management, 64, 251-264.

[26] Tasumi M. (2003). Progress in Operational Estimation of Regional Evapotranspiration using Satellite Imagery. PhD Dissertation, University of Idaho, College of Graduate Studies, USA.

[27] Herrero J. and Casterad Ma.A. (1998). IRRIVOL: a method to estimate the yearly ans monthly water applied in an irrigation district. Water Resources Research, 34,11,3045-3049.

[28] Herrero J. and Casterad Ma.A. (1999). Satellite and other data to estkimate the annua water demand of an irrigation district. Environmental Monitoring and Assessment, 55, 305-317., 34,11,3045-3049.

[29] Bastiaanssen W.G.M. (1999). The use of remote sensing to improve irrigation water management in developing countries, in (eds.) G.J.A. Nieuwenhuis, R.A. Vaughan and M.Molenaar, Operational Remote Sensing for Sustainable Development, A.A. Balkema, Rotterdam, ISBN 90 5809029 9, pp.3-17.

[30] Stewart J.B., Engman E.T., Feddes R.A. and Kerr Y.H. (1998). Scaling up in hydrology using remote sensing: summary of a Workshop. Int. J. Remote Sensing, 19, 1, 181-194.

[31] Lakshmi V. and Susskind J. (2001). Utilization of satellite data inland surface hydrology: sensitivity and assimilation. Hydrol. Process, 15,.877-892.

[28] Boni g., Entelhabi D. and Castelli F. (2001). Land data assimilation with satellite measurements for the estimation of surface energy balance components and surface control evaporation. Water Resources Research, 37, 6, 1713-1722.

[29] Morse A., Tasumi M., Allen R.G. and Kramber W. (2000). Application of the SEBAL Methodology for Estimation Consumptive Use of Water and Streamflow Depletion in the Bear River Basin of Idaho through Remote Sensing. http://www.idwr.state.id.us/gisdata/ET/Final\%20Report.pdf.

[30] Xiao X., He L., Salas W., Li C., Moore III B., Zhao R., Frolking S. and Boles S. (2002). Quantitative relationships between field-measured leaf area index and vegetation nindex derived fron VEGETATION images for paddy rice. Int. J. Remote Sensing, 23, 18, 3595-3604.

[31] Santos, E. (2003). Delimitación de áreas propensas a salinización mediante mapas de riego y de suelos. Proyecto del Postgrado de Ingeniería Medio Ambiental. Centro Politécnico Superior. Universidad de Zaragoza, pp.81. 